\title{
Translations
}

\section{ON EMINESCU'S PHILOSOPHY OF HISTORY: TOWARDS AN ENGLISH ANTHOLOGY OF RELEVANT TEXTS}

\author{
Cătălin PAVEL \\ Ovidius University, Constanța \\ e-mail: catalin.pavel@univ-ovidius.ro
}

\begin{abstract}
The present paper aims to offer Anglophone researchers a selection of translated quotes from Mihai Eminescu's non-literary oeuvre, relevant to the philosophy of history of the most complex Romanian author of the nineteenth century. It should thus become possible to reconsider Eminescu's position within the concert of European philosophers of history. The fragments gathered here stem mainly from his activity as a cultural and political journalist, throughout which he voiced, albeit unsystematically, his views on history. Although he did not ultimately articulate an academic philosophy of history per se, these fragments, now available in English for the first time, may give valuable insights into Eminescu's conception of history. Above all else, they meaningfully complement whatever can be gleaned from Eminescu's already translated poetry or literary prose. Hopefully the fragments presented here will aid scholars in establishing more precisely what Eminescu's views on history owe to Schopenhauer's metaphysics and what to the proper philosophy of history he could find in Hegel. This is a double allegiance scholars have also recognized in Maiorescu's work. By the same token, it would further be important to chart Eminescu's ambivalence towards Hegel, an ambivalence also visible in the works of Romanian philosopher Vasile Conta. Finally, the fragments below may help to bring to the fore the complex interplay between Hegelian theodicy and Kantian teleology in Eminescu's historical thought.
\end{abstract}

Keywords: Mihai Eminescu; philosophy of history; traductology; Hegel;

The present paper aims to offer Anglophone researchers a selection of translated quotes from Mihai Eminescu's non-literary oeuvre, which is relevant to the philosophy of history of the most complex Romanian author of the nineteenth century. It should thus become possible to reconsider Eminescu's position within the concert of European philosophers of history. The fragments gathered here stem mainly from his activity as a cultural and political journalist, throughout which he voiced, albeit unsystematically, his 
views on history. Although he did not ultimately articulate an academic philosophy of history per se, these fragments, now available in English for the first time, may give valuable insights into Eminescu's conception of history. Above all else, they complement in a meaningful manner whatever can be gleaned from his poetry or literary prose as already translated (e.g. by Giurgea, Eminescu, 1995; see also an analysis of historical nooks and crannies in "Luceafărul" in Noica, 2009).

Only a handful of the non-literary fragments germane to this topic have been transposed into an international language so far. They are nonetheless scattered in various publications. Kanterian (2013: 52), for example, offers a translation of a passage from an 1871 letter to Dumitru Brătianu, wherein Eminescu wrote:

"If a generation has any merit, it is that of being a faithful agent of history, to carry out the duties imposed with necessity by the place it occupies in the course of ages. The history of the world reasons as well - slowly, but with certainty and justice: the history of mankind is the development of the thought of God" (Kanterian, 2013: 52).

Similarly, C. Folschweiller (2010a: 245) translated (into French this time) the following passages: "Les peuples ne sont pas des produits de l'intelligence, mais de la nature" (Eminescu, 1999: 101)...

\begin{abstract}
“Nous croyons pouvoir établir une vérité générale: l'État n'est pas un produit de la raison mais de la nature. Il ira bien lorsqu'il se conformera à ses lois innées de développement, quand la raison jouera le rôle du médecin, qui ne fait que subvenir à l'action de la nature; il ira mal chaque fois que sa vie ne suivra pas un cours naturel, quand la raison, au lieu de s'accorder avec sa nature, en fera l'objet d'expériences irréfléchies» (Eminescu, 2000: 19).
\end{abstract}

It is to be hoped that the couple dozens new fragments translated below will create a sounder basis for evaluating the way in which Eminescu built on and how he parted ways with - various European philosophers of history.

\title{
Eminescu and the German philosophy of history
}

Paramount for understanding the development of Eminescu's ideas on history were undoubtedly his years as a visiting student in Vienna and Berlin (1869-1874). There he was inevitably exposed to the German philosophy of history, and particularly to Herbart, Kant, Schopenhauer, and Hegel. According to Edward Kanterian's summary, such ideas were bound to be sparked while Eminescu attended Eduard Zeller's lectures on German philosophy since Leibniz and those of C.V. Althaus, entitled Eine 
Entwicklung und Kritik der Principien der Hegelschen Philosophie. Eminescu's vision of history must have been further refined while he worked on the translation of significant parts of Kant's Kritik der reinen Vernunft, for which he had to coin a proper philosophical terminology in Romanian, and of a book by German theatre critic E.Th. Rötscher, Die Kunst der dramatischen Darstellung, itself imbued with Hegelian ideas (Kanterian, 2013: 51-52).

The passage from the 1871 letter to Brătianu, quoted above, can be correlated to Hegel's description of history as "the process of the Spirit of carrying forward the form of knowledge of itself [...] a slow procession and succession of spiritual manifestations" (52). For Eminescu however, a different individual spiritual manifestation takes the stage: the people almost completely determined by the past. In Kanterian's view, Eminescu's philosophy of history is more dualistic and deterministic than Hegel's, despite evolutionist elements, and can be summed up as "Hegel appropriated to local political purposes, quite intolerant ones" (52) The intolerance here, rooted in the spirit of the time, had to do with the fact that for Eminescu, when it came to the existence of a nation, and pace Hegel, not everything real was true, because, to quote Kanterian (52), "the co-existence with ethnicities alien to a nation's essence was possible but evil, created by human will". Since for Eminescu nations are a product of nature, rather than intelligence, it can be said that he aimed to replace the revolutionary ideology of 1848 (rationalist, universalist, and Republican) with a conservative view exalting adaptation to preexisting condition (Folschweiller. 2010a). The Romanian poet also endorsed, paradoxically, the social contract in a form of "social compensation", recast as the most rational solution to the natural conflict of selfish reasons (see Folschweiller 2010b on Rousseau and Follschweiller 2010a: 251 on Montesquieu). Another alleged departure from Hegel was detected by Folschweiller in Eminescu's naturalist-organicist sociology, and yet another one in Eminescu's less metaphysical views on the Constitution as the actual organism of the state (2010a: 257, 263).

It remains to be established - and hopefully the fragments below will aid scholars in that endeavor - what Eminescu's views on history owe to Schopenhauer's metaphysics and what to the proper philosophy of history he could find in Hegel. This is a double allegiance scholars have also recognized in Maiorescu's work (Ciomoș, 2006). By the same token, it would further be important to chart Eminescu's ambivalence towards Hegel, an ambivalence also visible in the works of Romanian philosopher Vasile Conta. Finally, it is to be hoped that the fragments below will help to bring to the fore the complex interplay between Hegelian theodicy and Kantian teleology in Eminescu's historical thought. 


\section{Note on the translation}

In translating these fragments it was considered profitable to eschew archaisms and to maintain a neutral language. This entailed doing away with words that are too obviously localized in modernity, but also with any attempt to make Eminescu sound like either Dickens or, for that matter, the King James's Bible. I also refrained from artificially making Eminescu any more poetical than he genuinely is: where he says "when he himself must submit his own atom" (using the word, "atom", which was exceedingly rare at the time, in the sense of minimal contribution), I resisted the temptation to use in translation something like "modicum". If Eminescu refers to the "lost son" of the parable, rather than using, as he easily could have, the word "prodigal", then the translator will retain "lost" and discard "prodigal". One fragment is translated from German since Eminescu found it easy to revert to the language of his studies when he found himself meditating on historical matters. He had in fact further honed his German skills by translating (in 1879) the first volume of the historical treatise Fragmente zur Geschichte der Rumänen. Those who have only read Eminescu's literary works are bound to be astonished by both the modernity and pugnacity of his style, by his longwinded phrases always ready to take a quantum leap from a concrete detail to a universal theme, as well as by the furious restlessness fueling his discourse - none of which is, alas, all that easy to capture in translation. Since clarity was the translator's main objective, occasionally phrases have been split into shorter sentences.

From M. Eminescu, Opere. Publicistică 1870 - 1877 Albina, Familia, Federaţiunea,

Convorbiri Literare, Curierul de Iaşi, vol. IX, Ed. Academiei Române, București, 1985.

\begin{tabular}{|c|c|}
\hline $\begin{array}{l}\text { IX, 171: Un mic bulgăr de omăt } \\
\text { căzând din vârful unui munte se face } \\
\text { din ce în ce mai mare, rupe cu el } \\
\text { copacii codrilor, strică ogoarele, } \\
\text { astupă un sat. Un mic sâmbure greşit } \\
\text { în organizaţia societăţii, în viaţa } \\
\text { economică creşte şi îngroapă o } \\
\text { naţiune. } \\
\text { AUSTRIACĂ } \\
\text { ROMÂNILOR DIN PRINCIPATE] }\end{array}$ & $\begin{array}{l}\text { IX, 171: A tiny snowball rolling } \\
\text { down from the top of a mountain } \\
\text { will become larger and larger, } \\
\text { uprooting the trees, destroying the } \\
\text { crops, covering up a village. A tiny } \\
\text { rotten kernel in the fabric of society } \\
\text { will grow and bury a nation. }\end{array}$ \\
\hline $\begin{array}{l}\text { IX, 241-242: În orice caz ni se pare } \\
\text { ciudat cum noi, românii, care trăim } \\
\text { lângă Dunăre, suntem cu totul }\end{array}$ & $\begin{array}{l}\text { IX, 241-242: In any case, we find it } \\
\text { strange that we, Romanians, living } \\
\text { along the Danube, should be utterly }\end{array}$ \\
\hline
\end{tabular}


cufundaţi în ideile Occidentului, pe când din toate părţile împrejuru-ne pulsează o viaţă istorică care în dispoziţia ei generală se deosebeşte atât de mult de istoria Occidentului . Câteodată ar trebui cel puţin să ni se pară că suntem o muche de despărţire între două lumi cu totul deosebite şi că este în interesul nostru de a cunoaşte amândouă lumile acestea. Occidentul îl cunoaştem îndestul. Misiunea sa în Orient este cucerirea economică, proletarizarea raselor orientale prin industria străină, prin robirea sub capitalul străin. Cealaltă parte a lumii o vedem din contra mişcată nu de un curent economic, ci de unul istoric şi religios, care nu poate lipsi de a exercita o mare atragere asupra popoarelor economiceşte puţin dezvoltate din Peninsula Balcanică, pentru cari credinţele bisericeşti şi idealele istorice sunt încă sfinte, nefiind pătate de materialismul modern. [29 octombrie 1896] [„NETĂGĂDUIT CĂ ISTORIA..."]

IX, 477: Popoarele mor de cele mai multe ori prin stingere fizică, mai arareori prin desnaţionalizare, iar acest din urmă caz e cu putinţă numai atunci când naţionalitatea $4 \mathrm{nu}$ e conştie de sine, când desnaţionalizarea e privită ca un fel de înaintare. Astăzi însă nu există aproape nici o limbă în Europa, fie cît de izolată, care, călcată pe urmele culturei antice, limpezită prin formele culturei clasice să nu fie în stare de-a cuprinde şi reda întreaga cultură omenească, de la abstracţiunea cea mai naltă pînă la espresiile cele mai immersed in Western ideas, whereas all around us pullulate forms of historical life which, in their general disposition, are so divergent from the history of the West. Sometimes we ought to at least imagine ourselves as a boundary between two entirely different worlds, and consider that it is in our best interest to be acquainted with both these worlds. We have a thorough knowledge of the West. Its mission in the East is economic conquest, the pauperization of Oriental races through foreign industry, through enslavement to foreign capital. Conversely, we perceive the other part of the world as being animated not by an economic undertow, but by a historical and religious one, sure to greatly fascinate the economically underdeveloped peoples in the Balkan Peninsula, who still hold religious beliefs and historical ideals to be holy, because unscathed by modern materialism.

IX, 477: Peoples generally die out by being physically extinguished and, more rarely, by being denationalized. The latter case is only possible when a nation has no selfawareness, when being denationalized is perceived as being some kind of progress. Today, however, there is almost no language in Europe, no matter how isolated, which, after having trodden in the footsteps of ancient civilization and having been purified by the forms of classical culture, should remain unable to encompass and reproduce 


\begin{tabular}{|c|c|}
\hline $\begin{array}{l}\text { concrete. [„DEZLEGAREA } \\
\text { CESTIUNEI ORIENTULUI..."] }\end{array}$ & $\begin{array}{l}\text { the entire culture of humanity, from } \\
\text { its highest abstraction to its most } \\
\text { concrete expressions. }\end{array}$ \\
\hline $\begin{array}{l}\text { IX, 459: Progresul omenirei nu zace } \\
\text { adesea în mulţimea geniilor săi - } \\
\text { naţiuni cu } 264 \mathrm{v} \text { genii străluciţi sunt } \\
\text { adesea nefericite }- \text { ci în acele } \\
\text { personagii mute ale istoriei care } \\
\text { lucrează neobosit, fără altă răsplată } \\
\text { decât conştiinţa datoriei împlinite, în } \\
\text { fine progresul e în toţi, nu în unul or } \\
\text { în unii. [,,DOMNILOR, } \\
\text { PROGRESUL OMENIREI..."] frg. } \\
\text { 2259 }\end{array}$ & $\begin{array}{l}\text { IX, 459: Mankind's progress often } \\
\text { lies not in the number of its geniuses } \\
\text { - nations with brilliant geniuses are } \\
\text { often unhappy - but in those } \\
\text { voiceless figures of history, who toil } \\
\text { ceaselessly, with no other reward } \\
\text { than the sense of fulfilled duty. } \\
\text { Indeed, progress is in all, not in one, } \\
\text { or in some. }\end{array}$ \\
\hline
\end{tabular}

M. Eminescu, Opere. Publicistică 1 noiembrie 1877 - 15 februarie 1880 „Timpul", Vol. X, Ed Academiei Române, București, 1989.

\begin{tabular}{|c|c|}
\hline $\begin{array}{l}\text { X, 153: În realitate omul e tot aşa de } \\
\text { puţin liber precum e picătura de } \\
\text { ploaie ce cade sau unda ce curge la } \\
\text { vale, iar nu la deal, aşadar despre o } \\
\text { libertate absolută, în sens metafizic, } \\
\text { nu poate fi nici vorba, prin urmare } \\
\text { nici despre o libertate a omului } \\
\text { supraordinată libertăţilor lui. Foarte } \\
\text { cu greu ni s-ar putea da definiţia unei } \\
\text { asemenea libertăţi abstracte şi } \\
\text { absolute şi, chiar daca ni s-ar da, ea } \\
\text { n-ar putea fi exactă, căci ar trata } \\
\text { despre un obiect a cărui existenţă nu } \\
\text { s-a putut dovedi pînă acuma. } \\
\text { Libertatea omului e mai mult o } \\
\text { noțiune istorică decît filozofică, o } \\
\text { serie de acte de eliberare succesivă, } \\
\text { un şir de libertăţi coordonate şi } \\
\text { cîştigate în curgerea timpurilor şi în } \\
\text { acest şir e cuprinsă şi libertatea } \\
\text { tranzacţiunilor. } \\
\text {...[N]ici averea noastră, nici } \\
\text { cultura generală nu ne-a făcut încă }\end{array}$ & $\begin{array}{l}\text { X, 153: In point of fact, man is no } \\
\text { freer than a falling raindrop, or water } \\
\text { flowing downhill rather than uphill, } \\
\text { thus there can be no question of } \\
\text { absolute freedom in a metaphysical } \\
\text { sense, nor, consequently, of a } \\
\text { freedom of man which is } \\
\text { superordinate to his liberties. It } \\
\text { would be very difficult to put } \\
\text { forward a definition for such an } \\
\text { abstract and absolute freedom, and } \\
\text { even if it were to be put forward, it } \\
\text { could not be precise, since it would } \\
\text { define an object whose existence is } \\
\text { yet to be proven. Man's freedom is a } \\
\text { historical notion rather than a } \\
\text { philosophical one, a series of } \\
\text { successive episodes of emancipation, } \\
\text { an array of liberties coordinated and } \\
\text { conquered over time (...). For all our } \\
\text { wealth and our education, we are still } \\
\text { not mature enough to fully exercise } \\
\text { such freedom. }\end{array}$ \\
\hline
\end{tabular}




\begin{tabular}{|c|c|}
\hline $\begin{array}{l}\text { maturi pentru exerciţiul deplin al } \\
\text { acestei libertăţi. } \\
\text { [5 decembrie 1878] }\end{array}$ & \\
\hline $\begin{array}{l}\text { X, 95: „Ca şi fiul pierdut din parabola } \\
\text { evangheliei, noi ne-am pierdut din } \\
\text { calea istoriei noastre adevărate, am } \\
\text { cheltuit în mare parte moştenirea } \\
\text { părintească pe formele goale ale unei } \\
\text { civilizaţii străine pe care n-am avut } \\
\text { nici timpul, nici mijloace îndeajuns } \\
\text { spre a ne-o apropria } \\
\text { X, } 97 \text { A face ce fac toţi, adecă a lua şi } \\
\text { stăpîni cu baioneta, e lucru uşor; a } \\
\text { păstra însă acest Orient în miniatură, } \\
\text { cu tot amestecul său de popoară, a } \\
\text { dovedi că sîntem destul de drepţi şi } \\
\text { destul de cumpătareţi ca să ţinem în } \\
\text { ecuilibru şi în bună pace elementele } \\
\text { cele mai diverse este o artă, este } \\
\text { adevărată politică pe lîngă care } \\
\text { politica forţei brute e o jucărie. } \\
\text { [ANEXAREA DOBROGEI] }\end{array}$ & $\begin{array}{l}\text { X, 95: Like the lost son in the Gospel } \\
\text { parable, we got lost along the path of } \\
\text { our true history way, we squandered } \\
\text { most of our parents' inheritance on } \\
\text { the empty forms of a foreign } \\
\text { civilization, lacking both the time } \\
\text { and the means to make it our own. } \\
\mathrm{X} \text {, 97: Doing what everybody else } \\
\text { does, that is, seizing and ruling by } \\
\text { means of the bayonet, is easy. } \\
\text { However, holding on to this } \\
\text { miniature Orient, with all of its } \\
\text { amalgamation of peoples, proving } \\
\text { that we are equitable and even- } \\
\text { tempered enough to maintain the } \\
\text { balance and peace for its extremely } \\
\text { diverse denizens - that is an art, it is } \\
\text { true politics, as opposed to the } \\
\text { politics of brute-force, which is a } \\
\text { farce. }\end{array}$ \\
\hline $\begin{array}{l}\mathrm{X}, 59: \text {,o vreme ca aceea a lui Rurik } \\
\text { sau a lui Oleg, în care istoria e mit şi } \\
\text { mitul istorie" }\end{array}$ & $\begin{array}{l}\mathrm{X}, 59 \text { : times like those of Rurik and } \\
\text { Oleg [of Novgorod], when history is } \\
\text { myth and myth is history }\end{array}$ \\
\hline $\begin{array}{l}\text { X, 74: „În tendenţele de cucerire, în } \\
\text { aşa-numitele misiuni istorice cari-şi } \\
\text { caută marginile naturale nu e nimic } \\
\text { dedesupt decît pur şi simplu neştiinţa } \\
\text { şi gustul de spoliare. În zadar caută } \\
\text { un popor în întinderi teritoriale, în } \\
\text { cuceriri, în războaie ceea ce-i lipseşte } \\
\text { în chiar sufletul lui; sub nici o zonă } \\
\text { din lume nu va găsi ceea ce } \\
\text { Dumnezeu i-a refuzat sau mai bine } \\
\text { zicînd ceea ce Dumnezeu a voit ca să } \\
\text { fie rezultatul muncii a multe generaţii } \\
\text { dedate la lucru. Căci stă oare } \\
\text { destoinicia unei naţii în vrun raport } \\
\text { cu întinderea teritoriului pe care ea-1 } \\
\text { ocupă?” }\end{array}$ & $\begin{array}{l}\text { X, 74: Behind the propensity for } \\
\text { conquest, behind those so-called } \\
\text { historical missions, which test their } \\
\text { natural limits, there is nothing but } \\
\text { mere ignorance and a taste for } \\
\text { plunder. In vain shall a people } \\
\text { search, in the expanse of land, in } \\
\text { conquests, in wars, for that which it } \\
\text { lacks in its very soul. In no realm of } \\
\text { the world will it find that which God } \\
\text { denied it, or, better yet, that which } \\
\text { God intended to be the result of the } \\
\text { toil of many generations' daily grind. } \\
\text { For is there any connection between } \\
\text { the worthiness of a nation and the } \\
\text { size of the land it inhabits?" }\end{array}$ \\
\hline
\end{tabular}




\begin{tabular}{|l|l|}
\hline [TENDENŢE DE CUCERIRE] [7 \\
apr. 1878]
\end{tabular}

M. Eminescu, Opere. Publicistică 17 februarie - 31 decembrie 1880

Timpul, Vol. XI, Ed. Academiei, București 1984

XI, 22-23: În republică domneşte îndeosebi interesul individual, în genere interesul de partid. (...) Această stare de lucruri e în aceeaşi proporţie lipsită de pericole în care esistă în stat o clasă de mijloc economiceşte puternică şi cultă care să mănţină echilibrul între tendinţele prea înapoiate a simţului istoric a unui popor, reprezentat în genere prin formele existente ale unei civilizaţii trecute, şi între tendenţele zgomotoase ale trebuinţelor acute ale prezentului, reprezentate prin nevoile claselor de jos. Unde această clasă nu există decît în mod rudimentar sau unde ea este prea slabă pentru a se împotrivi tendenţelor estreme republica devine $o$ jucărie a partizilor, o forma de care abuzează şi "unii şi alţii în detrimentul vădit al intereselor generale.

Deie-ni-se voie a arăta că ideea statului, ideea armoniei intereselor există în realitate, că statul nu este
XI, 22-23: In a Republic the interest of the individual reigns supreme, and more generally the interest of the party. (...) This state of facts is free of danger only insofar as there is within the state a cultured and economically potent middle class, which can keep in check the balance between the backward tendencies of the people's sense of history, as generally represented by the enduring forms of a past civilization, and the boisterous tendencies of the urgent demands of the present, as represented by the needs of the lower classes. Where this class's existence is precarious, or where it is too weak to stave off extreme tendencies, the Republic becomes a mere toy for the parties, a form abused by both sides, to the obvious detriment of the public interest. (...) The state is not just a sum of individuals who coexist at a given moment, it represents the very possibility to correct the wrongs 
numai suma de indivizi ce coexistă intr-un moment dat, că el reprezentă însăşi putinţa de îndreptare a unor rele ce rezultă din instinctele nesocotite ale actualităţii.

(...) Dar statul nu este nici suma indivizilor coexistenţi. Căci dacă luăm individ cu individ am vedea lesne că marea, incalculabil de marea majoritate a oamenilor s-ar sus-trage bucuros, numai de-ar putea, şi de la plata de bir şi de la prestaţiuni şi de la recrutare, încît, oricît de recunoscută ar fi necesitatea unui interes general de fiecare în parte, totuşi, cînd e vorba ca el să subvie cu atomul său individual acelei necesităţi, instinctul său intim şi primitiv este de a se sustrage. (...)

A pune dar acest instrument gingaş al statului, acest reprezentant atît al vieţii istorice cît şi al armoniei intereselor unei naţii, la discreţia absolută a unui singur partid este periculos, mai cu seamă cînd elementul ponderator al unei clase de mijloc culte şi avute e reprezentat numai într-un mod rudimentar.

[„,STUDII ASUPRA SITUATIEI”] [21 feb. 1880]. which ensue from the reckless instincts of contemporaneity.

(...) Indeed, if we were to focus on each individual, we would clearly see that the majority, the vast majority of people would gladly dodge - if only they could - their obligations such as taxes, public duties, or military service. Regardless of the extent to which a given individual acknowledges the preeminence of the general interest, when he himself must submit his own atom to that preeminent cause, his intimate and primitive instinct is to eschew paying his dues. (...) Therefore, placing the state, that delicate instrument, that representative of both historical life and a nation's harmony of interests, at the sole discretion of one party - is dangerous. It is particularly so when the arbitrator - a cultivated and wellto-do middle class - is only present in a very rudimentary form.

M. Eminescu, Opere. Publicistică, 1 ianuarie-31 decembrie 1881 Timpul, vol. XII, Ed. Academiei Române, București, 1985.

\begin{tabular}{|c|c|}
\hline $\begin{array}{l}\text { XII, } 149 \text { : Aristocraţia adevărată, } \\
\text { după a noastră părere, are un mare şi } \\
\text { esenţial rol în viaţa unui popor. Dar } \\
\text { pentru a fi adevărată [î }] \text { i trebuie } \\
\text { anume condiţii de existenţă, şi mai cu } \\
\text { seamă trei, fără de cari ea cată a fi } \\
\text { privită ca uzurpaţiune. Se cere să fie } \\
\text { istorică, puțin numeroasă, în }\end{array}$ & $\begin{array}{l}\text { XII, 149: Genuine aristocracy, in } \\
\text { our opinion, plays a great, indeed an } \\
\text { essential role in the life of a people. } \\
\text { However, in order for it to be } \\
\text { genuine, certain conditions of its } \\
\text { existence must obtain. Three such } \\
\text { conditions are paramount in the } \\
\text { sense that if they are not met, the }\end{array}$ \\
\hline
\end{tabular}


posesiune de mari bunuri imobiliare.

Sub ,istorică" înţelegem că trebuie să fi răsărit din dreptul public propriu al unui popor şi câştigată prin merite pentru el. E preferabil ca aceste merite să se datorească caracterului mai mult decât inteligenţei. Căci un caracter drept, viteaz şi generos se moşteneşte şi e o mare calitate politică, pe când inteligenţa se poate recruta din tot ce produce mai bun o generaţie, ea e aliata naturală a acestor caractere, dar din nefericire nu se moşteneşte cu atâta siguranţă. Apoi aristocraţia trebuie să fie puţin numeroasă, pentru ca alături cu ea să aibă loc meritele personale din orice generaţie; în fine trebuie să fie în posesiune de mari bunuri imobiliare, pentru că asemenea bunuri nu sunt supuse pericolului pierderii, îl fac pe om neatârnat de jocul banului şi-l pun în legătură cu brazda şi cu populaţia istorică a ţării. [26 aprilie 1881] [,„A DISCUTA CU IGNORANŢA ..."] aristocracy will be regarded as usurpation. Thus, it must be historical, scarce in numbers, and in possession of significant estates.

By "historical" we mean that it ought to have emerged out of a people's own public law, and to have been deserved by service to the people. It is to be preferred that its merits stem from character, rather than intelligence. For an honest, brave, and generous character is inherited and represents a great political quality, whereas intelligence can be recruited from amongst the best a generation has to offer, it is the natural ally of such character, but unfortunately it is not as positively inheritable. Furthermore, aristocracy must be scarce in numbers, so that it leaves enough room beside it for people of valor of any generation; finally, the possession of significant estates is important, since such assets are not subject to loss and their owners are not contingent on the money game and, at the same time, do not lose touch with the furrow and with the country's historical population.

XII, 154: formaţiunea demagogiei merge repede într-o ţară a cărei continuitate de dezvoltare istorică a fost nimicită prin dominaţiunea străină şi care este ea însuşi o creaţiune politică proaspătă. Când într-o ţară trecutul n-a distins pe omul de merit de cel de rând, când conştiinţa publică şi împrejurările sunt turburi şi departe încă de cristalizaţiune, ajung, ca şi la apa cea turburată, gunoiele deasupra. A striga
XII, 154: Demagogy spreads fast in a country whose continuity of historical development has been shattered by foreign domination and which is itself a recent political creation. In a country whose past has not sifted out the unworthy from the worthy man, and whose public conscience is as murky and uncrystallized as its circumstances, rubbish will find its way to the surface, as is the case with murky 
pe toate uliţele şi pe toate tonurile patrie, libertate, egalitate, fraternitate! nu e un merit nici la noi, nici în Bulgaria, nici undeva în lume. Dar cine nu are altul îşi creează din asemenea strigăte un titlu de recomandaţie.

XII, 374: naţionalitatea română ca oricare alta are dreptul înnăscut de aşi apăra moştenirea ei istorică şi munca ei de orice alt element străin. Alegerea armelor şi mijloacelor atârnă de timp şi împrejurări, şi, dacă e vorba de păstrarea rasei române pe acest colţ de pământ şi de întărirea caracterului ei şi a felului ei de-a fi, nici o armă nu este rea întrebuinţată la timpul cuvenit.

[20 octombrie 1881]

XII, 162 : Statele moderne nu se mai dezvoltă, din nefericire, în linie dreaptă, ci prin cotituri, adesea prin concesii, renunţând la maniera lor dea fi, la signatura existenţei lor. Sunt cristalizaţiuni imperfecte pe lângă câteva cristale perfecte pe cari le prezintă istoria. Asta e chiar deosebirea între naţii mici, fără simţ istoric , şi naţiile mari, c-un profund simţ istoric şi c-un mare viitor. [NU VOM DISCUTA CU ROMÂNUL PRINCIPII...

XII, 159-160 Cu toate acestea oricine va voi să definească marele mister al existenţei va vedea că el consistă în împrospătarea continuă a fondului şi păstrarea formelor. Forme vechi, dar spirit pururea nou. Astfel vedem cum Anglia, care stă în toate celea în fruntea civilizaţiei, păstrează şi astăzi waters. Shouting in the streets, in all tones of voice, "Motherland, Freedom, Equality, Fraternity!" is no merit, neither here, nor in Bulgaria nor indeed anywhere else in the world. However, he who has no other credentials will fabricate some out of such slogans.

XII, 374: The Romanian nation, just like any other, has the innate right to defend its historical heritage and its achievements in the face of all foreign elements. The choice of weapons and means depends on time and circumstances, and, if the preservation of the Romanian race in this corner of the world, and the building of its character and way of life are at stake, then no weapon should be inappropriate if resorted to at the right moment.

XII,162: Unfortunately, modern states no longer develop in a straight line, but through twists and turns, often by way of compromises, relinquishing their way of life, the signature of their existence. They are imperfect crystallizations alongside the few perfect crystals that history evinces. This is the very difference between small nations, with no sense of history, and great nations, with an engrained sense of history and a great future.

XII, 159-160: Nonetheless, anyone endeavoring to define the great mystery of existence will realize that it resides in the constant renewal of content with the preservation of form. Ancient forms, but a perpetually new spirit. This is why we see England, which is on all 
vechile sale forme istorice, pururea reâmprospătate de spiritul modern, de munca modernă. counts the spearhead of civilization, retain today its old historical forms, constantly rejuvenated by modern spirit, by modern toil.

vol. XIII: M. Eminescu, Opere. Publicistică 1882-1883, 1888-1889, „Timpul”, „România Liberă”, „Fîntîna Blanduziei”, Ed Academiei Române, București, 1985.

\begin{tabular}{|c|c|}
\hline $\begin{array}{l}\text { XIII, 89: Cercetările istorice, } \\
\text { filologice şi de psicologie poporană } \\
\text { n-ar prezinta un interes atât de viu } \\
\text { dacă am avea o epocă de înaltă } \\
\text { civilizație în urmă-ne, dacă fiinţa } \\
\text { noastră naţională s-ar fi păstrat, în } \\
\text { haina neîmbătrânirii, în scrierile unor } \\
\text { cugetători anteriori. Dar civilizaţia } \\
\text { noastră e falsă; străini şi semistrăini } \\
\text { născuţi în Bucureşti ori în oraşele de } \\
\text { pe Dunăre şi franţuziţi la Paris, } \\
\text { aceştia au falsificat şi drept, şi viaţă } \\
\text { publică, şi datini, au prefăcut } \\
\text { Cuventele den bătrâni în limba } \\
\text { păsărească a gazetelor şi a } \\
\text { pledoariilor dinaintea tribunalelor, } \\
\text { încât chiar dicţionarul limbei în } \\
\text { circulaţiune trebuie trecut prin } \\
\text { depănătoare şi ne vedem nevoiţi a } \\
\text { face istoria fiecării vorbe pe care-o } \\
\text { întrebuinţăm pentru a-i păstra } \\
\text { inţ̧̧elesul. } \\
\text { Am putea zice că e luptă de } \\
\text { toată ziua pentru toate bunurile } \\
\text { naţionalităţii noastre. ... Ceea ce se } \\
\text { dezgroapă prin aceste documente } \\
\text { istorice şi linguistice nu sunt dar } \\
\text { numai materialuri de interes } \\
\text { arheologic , ci e România însăşi, e } \\
\text { geniul poporului românesc de pe care } \\
\text { se înlăturează păturile superpuse de } \\
\text { ruine şi de barbarie. Fiece pas înainte } \\
\text { se face aci în înțelesul reconstruirii }\end{array}$ & $\begin{array}{l}\text { XIII, 89: Historical, philological, and } \\
\text { folk psychology research would not } \\
\text { be of such keen interest had we } \\
\text { superseded an era of consummate } \\
\text { civilization, had our national spirit } \\
\text { been preserved, cloaked in the } \\
\text { garment of timelessness, in the } \\
\text { writings of past thinkers. However, } \\
\text { our civilization is phony; foreigners } \\
\text { and half-foreigners born in } \\
\text { Bucharest or in the cities on the } \\
\text { Danube and Frenchified in Paris } \\
\text { have falsified law, public life and } \\
\text { traditions alike, have turned our } \\
\text { forefathers' words into journalistic } \\
\text { gobbledygook and court legalese } \\
\text { (..). We might say that there's a } \\
\text { daily battle for all of our nation's } \\
\text { assets. (...) What is being unearthed } \\
\text { with these historical and linguistic } \\
\text { documents are not mere } \\
\text { archaeological materials - it is } \\
\text { Romania herself, the genius of the } \\
\text { Romanian people, from which we } \\
\text { peel superimposed layers of debris } \\
\text { and backwardness. Each and every } \\
\text { step forward is taken towards the } \\
\text { reconstruction of the Romanian } \\
\text { nationality and in order for the latter } \\
\text { to acknowledge itself and come to its } \\
\text { senses. The biblical curse, "in the } \\
\text { sweat of thy face shalt thou eat } \\
\text { bread", was no curse at all, but a }\end{array}$ \\
\hline
\end{tabular}




\begin{tabular}{|c|c|}
\hline $\begin{array}{l}\text { naţionalităţii române şi pentru ca ea } \\
\text { însăşi să se recunoască pe sine, să-şi } \\
\text { vie în fire. Blestemul din Biblie, ,în } \\
\text { sudoarea frunţii tale îţi vei câştiga } \\
\text { hrana", n-a fost un blestem, ci o } \\
\text { binecuvântare. „În sudoarea frunţii } \\
\text { tale te vei cunoaşte pe tine însuţi" } \\
\text { zicem cercetătorilor pe terenul istoriei } \\
\text { şi a linguisticei bucuraţi de aceste } \\
\text { rezultate ale unei munci naţionale, } \\
\text { rezultate greu de câştigat în } \\
\text { comparare cu deprinderea mecanică a } \\
\text { formelor esterioare ale unei civilizaţii } \\
\text { străine. [1 aprilie 1882] }\end{array}$ & $\begin{array}{l}\text { blessing. "In the sweat of thy face } \\
\text { thou shalt know thyself" - this is } \\
\text { what we say to those conducting } \\
\text { historical and linguistic research. } \\
\text { Such a national enterprise delights } \\
\text { us, and its results are much harder to } \\
\text { harvest than it is to mechanically } \\
\text { appropriate the outer forms of } \\
\text { foreign civilization. }\end{array}$ \\
\hline $\begin{array}{l}\text { XIII, 190: Absolutismul nu este } \\
\text { pururea şi pretutindenea o nenorocire. } \\
\text { Adeseori el e necesar şi mari creaţiuni } \\
\text { istorice îi se datoresc. Dar.. . } \\
\text { absolutismul sincer, întemeiat ca atare } \\
\text { pe dreptul public al poporului, } \\
\text { absolutismul care nu se ruşinează de } \\
\text { sine însuşi şi care crede că, prin o } \\
\text { biurocraţie energică, cu învăţătură de } \\
\text { carte şi incoruptibilă, se poate } \\
\text { produce mai mult bine decât prin } \\
\text { discuţiile adese sterpe ale unor } \\
\text { parlamente inculte. Dar a avea un } \\
\text { absolutism bazat pe minciuna } \\
\text { parlamentară însemnează a avea o } \\
\text { companie de esploatare în capul ţării, } \\
\text { care, păzind cu ipocrizie formele } \\
\text { esterioare ale parlamentarismului, e } \\
\text { despotică nu în folosul statului şi al } \\
\text { populaţiunilor, ci în folosul [a] o } \\
\text { mână de oameni lacomi de avere şi } \\
\text { moraliceşte putrezi. } \\
\text { [17 septembrie 1882] [,FRIGURI DE } \\
\text { REFORME...”] }\end{array}$ & $\begin{array}{l}\text { XIII, 190: Absolutism is not always } \\
\text { and everywhere a calamity. It is } \\
\text { often necessary, and it has } \\
\text { engendered great historical creations. } \\
\text { A straightforward absolutism is } \\
\text { meant here, one based on the } \\
\text { people's public law, an absolutism } \\
\text { which is not ashamed of itself and } \\
\text { which upholds that, through an } \\
\text { industrious bureaucracy, educated } \\
\text { and incorruptible, more good can be } \\
\text { achieved than through the oftentimes } \\
\text { sterile debates of ignorant } \\
\text { parliaments. However, an absolutist } \\
\text { rule rooted in parliamentary deceit } \\
\text { comes down to appointing as the } \\
\text { head of the state an exploitation } \\
\text { company, which, while } \\
\text { hypocritically defending the outer } \\
\text { forms of parliamentarism, rules } \\
\text { tyrannically not for the benefit of the } \\
\text { state and the populations, but for that } \\
\text { of a handful of greedy and morally } \\
\text { bankrupt people. }\end{array}$ \\
\hline $\begin{array}{l}\text { XIII, 85: Poate nu e o idee nouă dacă } \\
\text { spunem că orice lucrare literară } \\
\text { însemnată cuprinde, pe lângă actul }\end{array}$ & $\begin{array}{l}\text { XIII, 85: It is perhaps not a novel } \\
\text { idea that any major literary work } \\
\text { contains, apart from the intellectual }\end{array}$ \\
\hline
\end{tabular}


intelectual al observaţiei şi conceperei , o lucrare de resumţiune a unor elemente preexistente din viaţa poporului. Sunt scriitori - şi numărul lor e legiune - cari sugându-şi condeiul în gură, scornesc fel de fel de cai verzi, creaţiuni ale fantaziei pure fără corelaţiune cu realitatea, creaţiuni ce, prin noutatea lor, atrag poate câtva timp publicul şi sunt la modă.

Credem că nici o literatură puternică şi sănătoasă, capabilă să determine spiritul unui popor, nu poate exista decât determinată ea însăşi la rândul ei de spiritul acelui popor, întemeiată adecă pe baza largă a geniului naţional. Aceasta nu e adevărat numai pentru literat, ci se aplică tot atât de bine la legiuitor, la istoric, la omul politic. $\mathrm{Nu}$ acel legiuitor va fi însemnat care va plagia legi străine traduse din codicile unor țări depărtate ce au trăit şi trăiesc în alte împrejurări, ci cel care va şti să codifice datina ţării lui şi soluţiunea pe care poporul în adâncul convingerilor sale o dă problemelor în materie.

$\mathrm{Nu}$ acel om politic va fi însemnat, care va inventa şi va combina sisteme nouă, ci acel care va rezuma şi va pune în serviciul unei mari idei organice înclinările, trebuinţele şi aspiraţiunile preexistente ale poporului său.

$\mathrm{Nu}$ acel istoric va fi exact, carele în fraze pompoase va lăuda sau va batjocori întâmplările în trista şi searbăda lor conexiune cauzală, ci acela care va căuta raţiunea de-a fi a acelor întâmplări şi va descoperi-o în endeavor of observation and conception, an attempt to epitomize pre-existing elements in the life of the people. There are writers - and their number is legion - who, while sucking on their quills, come up with all kinds of mumbo-jumbo, pure figments of imagination bearing no connection to reality, contrivances which, by dint of their novelty, may be fashionable and curry the favor of the public for a while. (...) We believe that no robust and healthy literature which is able to determine the spirit of a people, can exist in any other way than by being itself determined by the spirit of that people, in other words, founded on the broad basis of the national genius. This does not hold solely for the man of letters, but equally applies to the lawgiver, to the historian, to the statesman. An important lawgiver is not the one who plagiarizes foreign legislation, translated from the statutes of remote countries, which are and were subject to different circumstances but the one who will fathom how to create a code of laws out of his country's traditions and the solutions given to such issues by the people, ensuing from its deep convictions.

An important statesman is not the one who invents and combines new systems, but the one who will epitomize his people's pre-existing proclivities, needs, and aspirations, and put them in the service of a grand, organic vision. A precise historian is not the one who, in bombastic phraseology, will extol or 


\begin{tabular}{|c|c|}
\hline $\begin{array}{l}\text { adâncimea geniului popular. Unul ca } \\
\text { acesta ar descoperi că aceleaşi raţiuni } \\
\text { cari au făcut pe români să crească i-au } \\
\text { făcut să şi cază; aceleaşi calităţi cari } \\
\text { au urcat pe osmani la înălţimea de } \\
\text { stăpânitori a trei continente au fost } \\
\text { rădăcinile pieirii lor; că orice calitate, } \\
\text { orice energie, orice e mare şi puternic } \\
\text { ca patimă are în consecuenţa cu sine } \\
\text { însuşi rădăcinile fericirii şi nefericirii } \\
\text { sale. Numai oamenii cari au tăria de-a } \\
\text { fi credincioşi caracterului lor propriu } \\
\text { fac impresie în adevăr estetică, ei } \\
\text { numai au farmecul adevărului, } \\
\text { reprezintarea lor zguduie adânc toate } \\
\text { simţirile noastre şi numai aceasta e } \\
\text { obiectul artei. } \\
\text { [”NOVELE DIN POPOR DE IOAN } \\
\text { SLAVICI”] }\end{array}$ & $\begin{array}{l}\text { ridicule events in their sad and bland } \\
\text { causality, but the one who looks for } \\
\text { the rationale of those events and } \\
\text { discovers it in the depths of the } \\
\text { popular genius. Such a historian will } \\
\text { discover that the very reasons which } \\
\text { made Romanians rise, also made } \\
\text { them fall; the same qualities that } \\
\text { made the Ottomans become rulers of } \\
\text { three continents were also the roots } \\
\text { of their undoing; that any virtue, any } \\
\text { energy, anything of great and intense } \\
\text { passion necessarily carries with it the } \\
\text { very roots of its happiness and } \\
\text { unhappiness. Only people who have } \\
\text { the stamina to be true to their own } \\
\text { character can truly have an aesthetic } \\
\text { impact, only they possess the charm } \\
\text { of the truth. Their depiction deeply } \\
\text { shakes our senses - and this alone } \\
\text { can be the subiect of art. }\end{array}$ \\
\hline
\end{tabular}

vol XV: M. Eminescu, Fragmentarium, Addenda ediției. Ed Academiei Române, București, 1993.

$\mathrm{XV}, 87$ : Cine va vrea să facă istoria unei epoce sau a unui mişcământ oarecare înainte de toate va trebui să facă a se simţi legea continuităţii acestui mişcământ. El va trebui să caute punctul de purcedere, de ajungere, şi apoi seria terminelor intermediare prin cari se află unite aceste două termine estreme. El va trebui încă să se silească a arăta duplul mecanism de repulsiune şi asimilaţiune pe care 1-am indicat şi prin mijlocul căruia el s-a efectuat.

Istoricul se va ataşa de-o idee şi această idee el o va urma de la originea sa până la ultimul termin al dezvoltării sale, cum s-ar zice prin
$\mathrm{XV}$, 87: Whoever shall attempt to write the history of a time period or of a certain movement shall above all endeavor to bring to the fore the law of continuity of this movement. He shall have to seek out the departure and arrival points, and then the series of intermediary stages connecting these two extreme points. Moreover, he shall have to exert himself to emphasize the aforementioned double mechanism of rejection and assimilation, and through which the movement was effected.

The historian shall focus on one idea and pursue this idea from its inception to the final phase of its 
mijlocul aventurelor ei celor mai diverse; ea va fi personagiul şi eroul cărţii. Sistemele la cari va fi fost baza şi fundamentul vor fi ca învelitorile esterioare, ca fazele diverse a dezvoltării sale; oamenii mari ce vor fi esprimat-o nu vor fi decât organe; personalitatea lor se va nimici în personalitatea ideei. Astfel vom avea într-adevăr istoria cutărui sau cutărui mişcământ, iar [nu] a cutărei sau cutărei fapte izolate, cari nu sunt decât pe-atâtea episoade.

Ş-apoi, dacă aceasta nu va fi numai cutare sau cutare idee, a căreil curs istoricul [î]l va cerceta în modul acesta, dacă asta va fi ideea în ea însăşi, se va putea vedea în germenele său, tot atât ca şi în succesiunea, în simultaneitatea, tot în vremea continuităţii sale, toată dezvoltarea istorică. Vom citi c-o singură aruncătură de ochi toată opera istoriei.

\section{[O PROBLEMĂ A ISTORICULUI]}

Principii generale, conducătoare, cari caracterizează epocele, nu sunt nimic mai puţin decât conducătoare, ele sunt monogramul în care se prezintă aspiraţiunile generaţiuneil dintr-un popor; în sine luate [sunt] mişcarea acelor puteri2 vii în direcţia vieţii publice care rămân neocupate sau neocupabile3 de lucrarea economică a lui. [„PRINCIPII GENERALE...”] 2258

$\mathrm{XV}, 88$ Darum ist auch leicht erklärlich warum in Politik $u[n d]$ Moralität ein[er] etwas lobt, ein anderer tadelt. Nicht der Intellekt thut development, so to speak across its most diverse exploits; it is this idea that will be the character and protagonist of the book. The systems whose groundwork and foundation it will have formed will resemble external accoutrements, diverse stages of its development; great men who have expressed it will be mere instruments; their personality will dissolve into the personality of the idea. Only in this fashion will we genuinely produce the history of a certain movement, not that of isolated events, which are nothing but episodes.

Furthermore, if this will be not just a certain idea, whose avatars the historian will investigate in the aforementioned manner, if this indeed be rather the idea in itself, then one shall be able to see a whole historical development in its very inception, as well as in its progress, in its simultaneity, in its continuity. We shall read at a glance the workings of history as a whole.

$$
\text { * }
$$

General moving principles, which characterize a time period, are nothing short of moving. They are the monogram which epitomizes the aspirations of a people's generation; they incorporate the dynamics of those living forces striving for public life, forces which remain unoccupied or unoccupiable by the people's economic endeavors.

$\mathrm{XV}$, 88: Therefore, it is not difficult to explain why, in politics and morals, what one praises, another castigates. It is not the intellect that 
es, sondern der Wille vermittels des Intellektes, - der Urtheil des reinen Intellekts ist immer gerecht. Die Logik der Geschichte ist Eristik u[nd] Sophisterei, die Leute beweisen nicht, weil es von selbst folgt, also aus reinem Interesse für die Wahrheit, sondern weil sie es beweisen wollen. [LOGICA ISTORIEI] 2287

*

Cumcă oamenii ştiu istorie fără să-nveţe nimic de la ea e un semn că istoria este voinţă şi nu teorie, că se poate învăţa şi — alea non discitur. Inteligenţa este condamnată a juca rolul de salahor al voinţei, cum se vede aceasta în jurnale şi în opinia publică în genere. Ea este într-adevăr l'avocat du diable, precând toată filozofia istoriei e concentrat[ă] în fraza latină : Stat pro ratione voluntas. De aceea în genere toată literatura politică, toată istoria optimistă, toată, toată filozofia, care rezumă în sine starea de bucurie sau neplăcere a unei epoce şi e espresia, fizionomia ei, nu sunt decât tot atâtea pagine ale opului l'avocat du diable. De-aceea şi este de un timp zisă, de altul dezisă, este vină în ele, este interes, este voinţă. Adevărat nemuritoare, inocente în felul lor sunt numai acele producte născute dintr-o mare superfluenţă a creierului, care a paralizat sau cel puţin s-a eliberat pe deplin de voinţă. În van vei spune că istoria învaţă, că războaie, ură, nedreptăţi, răutate nu duc decît la o esistenţă efemeră, va să zică la nimic, căci, într-un timp nemărginit, un secol e o clipă suspendată. effects this, but the will, by means of the intellect. The judgement of the pure intellect is always just. The logic of history is heuristics and sophistry. People do not prove something because it is truly provable, that is, out of pure interest for the truth, but because they want to prove it.

That people have a knowledge of history without learning anything from it is a sign that history is will, and not theory, that it can be learned and that - alea non discitur [the die cannot be learned]. Intelligence is doomed to play the role of a farmhand for the will, as can be witnessed in the newspapers and in the public opinion in general. It is indeed l'avocat du diable, whereas all philosophy of history is concentrated in the Latin adage: Stat pro ratione voluntas [The will stands in place of a reason]. That is why generally all political literature, all optimistic history, indeed all philosophy, which encapsulates the whole state of elation or discontent of an epoch and constitutes its expression, its physiognomy, are nothing but as many pages in an opus titled l'avocat du diable. (...) Truly immortal, innocent in their own way, are only those products born out of an overabundance of the brain, which has paralyzed the will or at least has freed itself from it. It is pointless to say that history is a teacher, that wars, hatred, injustice, wretchedness only engender a fleeting existence, boiling down to nothing, because, 


\begin{tabular}{|l|l|}
\hline $\begin{array}{l}\text { [,,STAT PRO RATIONE } \\
\text { VOLUNTAS”] } 2287\end{array}$ & $\begin{array}{l}\text { within endless time, one century is } \\
\text { merely a suspended moment. }\end{array}$ \\
\hline $\begin{array}{l}\text { XV, 97: Istoria - un necrolog. } \\
\text { [,ISTORIA...”] } 2262\end{array}$ & $\mathrm{XV}, 97$ : History - an obituary. \\
\hline
\end{tabular}

Acknowledgments: Eminescu's texts presented in this paper have been translated during my research stage as a Fellow of Memorialul Ipotești, whose director, Ala Sainenco, I offer my warmest thanks. I would also like to thank Iuliana Petrescu (Babeș-Bolyai University) for her valuable comments on a draft of this translation. My gratitude to the editors and anonymous reviewers of SJRS for considering this paper.

\section{References:}

Ciomoş, V. (2006). Le Hégélianisme roumain: Constantin Noïca et la Logique de Hegel/ Romanian Hegelianism. Constantin Noica and the Logic of Hegel. In J. -L. Vieillard-Baron, \& Y. C. Zarka (Eds.), Hegel et le droit naturel moderne/Hegel and Modern Natural Law. Paris: Vrin. pp. 215-240.

Eminescu, M. (1995). The Complete Prose Writings of Mihai Eminescu. (Ioan Giurgea, Trans). Iaşi: Center of Romanian Studies.

Eminescu, M. (1999). Influenţa austriacă asupra românilor din Principate/ The Austrian Influence on the Romanians in the Principalities. In Opere/Complete Works. Vol. III. Publicistică. Corespondenţă. Fragmentarium./ Journalism. Letters. Fragmentarium. Bucharest: Univers Enciclopedic.

Eminescu, M. (2000). Opere/ Complete Works Vol. V. Publicistică/ Journalism. Bucharest: Univers Enciclopedic.

Folschweiller, C. (2010a). Les ambiguïtés de la thèse de l'État naturel et du modèle organiciste à Junimea/ The Ambiguities of the Natural State Thesis and of the Organicist Model by Junimea. Studia Politica: Romanian Political Science Review, 10(2), 245-264.

Folschweiller, C. (2010b). Eminescu et l'État. Un pacte social sur des fondements schopenhaueriens/ Eminescu and the State. A Social Contract on Schopenhauerian Foundations, Studia Politica: Romanian Political Science Review, 10(1), 103-121.

Kanterian, E. (2013). Hegel's Tale in Romania. In L. Herzog (Ed.), Hegel's Thought in Europe: Currents, Crosscurrents and Undercurrents (pp. 49-68). Palgrave Macmillan: Basingstoke. https://doi.org/10.1057/9781137309228_4

Noica, N. (2009). Six Maladies of the Contemporary Spirit. Plymouth: University of Plymouth Press. 